\title{
Penggunaan aplikasi augmented reality untuk memfasilitasi penguasaan konsep peserta didik tentang siklus hidup tumbuhan dan keterampilan berpikir kreatif
}

\section{(The use of augmented reality application to facilitate the understanding of students about} plant life cycle and creative thinking skills)

\author{
Fitri Husni Mardiyah*, Ari Widodo, Diana Rochintaniawati \\ Departemen Pendidikan Biologi FPMIPA Universitas Pendidikan Indonesia, Jl. Dr. Setiabudhi No. 229 Bandung \\ *Corresponding author: husnifitri8@gmail.com
}

Received: 24 July 2020 - Accepted: 2 September 2020 - Published: 30 September 2020

\begin{abstract}
Augmented reality application-based learning is one form of education reforms that is used to improve various skills that are needed. One of them is creative thinking skills to face the challenges of the 21 st century or the challenges of the industrial revolution 4.0 today. Therefore, the researcher conducts a study entitled the use of augmented reality application to improve the understanding of plant life cycle and creative thinking skills. This study aims to analyze the effects of the use of augmented reality application based on the improved understanding of students about the plant life cycle and creative thinking skills. This study uses the method of quasi-experimental design. The used study design is non-eqivalent control group pretestpostest design. The samples in this study are grade X students of SMA 2 Lembang consisting of 30 students determined by purposive sampling technique. The results of this study show that there are significant differences in the understanding of the concept and creative thinking skills of the students, although the creative thinking skills in both classes are still in the poor category., it is due to the application media of augmented reality application is only used as a medium of learning without including the making process of it so students are not accustomed when they are faced with questions in the form of problem. The test of two averages on the value of concept understanding shows the figure of $(2$-tailed $t=0$ and 0,001$)<\alpha(0.05)$ which means that augmented reality application-based learning has an influence on students 'mastery of concept concepts, but does not affect the ability of participants' creative thinking skills students.
\end{abstract}

Keywords augmented reality application-based learning, creative thinking skills, the life cycle of angiosperms and gymnosperms

\begin{abstract}
ABSTRAK Pembelajaran berbasis aplikasi angmented reality merupakan salah satu bentuk reformasi pendidikan yang digunakan untuk meningkatkan berbagai keterampilan yang dibutuhkan salah satunya adalah keterampilan berpikir kreatif untuk menghadapi tantangan abad ke-21 atau saat ini adalah tantangan revolusi industri 4.0. Maka dari itu peneliti melakukan suatu penelitian yang berjudul penggunaan aplikasi augmented reality untuk meningkatkan Penguasaan siklus hidup tumbuhan dan keterampilan berpikir kreatif. Penelitian ini bertujuan untuk menganalisis pengaruh penggunaan aplikasi berbasis Augmented reality terhadap peningkatan Penguasaan peserta didik tentang siklus hidup tumbuhan dan keterampilan berpikir kreatif. Penelitian ini menggunakan meetode quasi experimental design. Desain penelitian yang digunakan adalah non eqivalent control group design. Sampel pada penelitian ini adalah siswa kelas X SMA Negeri 2 Lembang yang terdiri dari 30 orang peserta didik ditentukan dengan teknik purposive sampling. Hasil penelitian ini menunjukkan terdapat perbedaan yang signifikan pada penguasaan konsep namun tidak berpengaruh terhadap keterampilan berpikir kreatif peserta didik, walaupun pada keterampilan berpikir kreatif pada kedua kelas masih pada kategori kurang, hal tersebut karena media aplikasi angmented reality hanya digunakan sebagai media pembelajaran tanpa diikut sertakan untuk membuatnya sehingga ketika peserta didik diberikan soal berbentuk masalah mereka tidak terbiasa untuk mengerjakannya. Uji dua rerata pada nilai penguasaan konsep menujukkan angka (2-tailed $=0$ dan 0,001$)<\alpha(0,05)$ yang berarti bahwa pembelajaran berbasis aplikasi augmented reality memiliki pengaruh terhadap penguasaan konsep peserta didik, namun tidak berpengaruh terhadap kemampuan keterampilan berpikir kreatif peserta didik.

Kata kunci Pembelajaran berbasis aplikasi augmented reality, keterampilan berpikir kreatif, siklus hidup tumbuhan angiospermae dan gymnospermae
\end{abstract}

\section{PENDAHULUAN}

Revolusi Industri ke-4 sedang berlangsung di dunia, saat ini berkembangnya teknologi digital dan bioteknologi tidak lagi berkembang dalam disiplin ilmu masing-masing, tetapi bergabung dan terintegrasi untuk mengembangkan teknologi sebagai solusi dari sebuah masalah juga mempermudah pekerjaan manusia (Guoping et al., 2017).
Teknologi pada masa revolusi industri ke-4 ini memiliki paras sentral yang sangat berhubungan erat dengan kehidupan masyarakat luas, namun dalam penggunaannya masih belum bisa berfokus untuk peningkatan kualitas masyarakat atau membantu kehidupan masyarakat umum. Perkembangan teknologi yang terjadi pada masa Revolusi Industri ke-4 ini tidak hanya berdampak pada bidang ekonomi saja namun berkembang pula pada bidang lain 
termasuk pendidikan, baik dalam kegiatan pembelajaran sehingga hasil pembelajaran yang diharapkan dapat membentuk pribadi yang siap menghadapi kemajuan di bidang teknologi pada masa sekarang sekaligus masa depan. Salah satu keterampilan yang perlu dimiliki oleh penduduk dunia yang menjadi bagian dari Revolusi Industri ke-4 adalah keterampilan berpikir kreatif, karena banyak bagian dari kehidupan untuk masa depan yang telah bergantung pada pemikiran yang kreatif agar tetap memiliki daya saing (Ilomäki et al., 2014).

Saat ini sedang hangat diperbincangkan media pembelajaran berbasis teknologi digital yaitu augmented reality. Augmented reality adalah salah satu teknologi yang dapat membantu pembelajaran di sekolah yang digunakan untuk memvisualisasikan suatu yang abstrak menjadi lebih jelas (Mustaqim, 2016). Selain itu, menurut (Hsu et al., 2017) melalui augmented reality guru dapat membuat media pembelajaran yang menyenangkan, interaktif, dan mudah digunakan. augmented reality juga dapat menggantikan pembelajaran yang belum ada di sekolah dalam bentuk virtual atau maya. Melaui terobosan baru ini, semakin banyak variasi media pembelajaran yang dapat dibangun untuk mendukung kegiatan pembelajaran di sekolah.

Pembelajaran berbasis Augemented Reality ini dapat membantu meningkatkan minat peserta didik mempelajari konsep-konsep yang terbilang abstrak dan sulit untuk digambarkan, misalnya penjelasan mengenai anatomi (Torralba, 2015). Banyak materi pembelajaran khususnya dalam mata pelajaran biologi yang terkesan abstrak, hal ini karena umumnya materi pembelajaran dalam biologi melibatkan suatu proses yang sulit untuk dilihat secara langsung dan membutuhkan waktu yang tidak sebentar. Selain kesulitan untuk memahami hal yang abstrak, kesulitan dalam menunjukan dibagian mana proses tersebut secara spesifik pun dianggap sulit karena terdapat bagian yang terkadang tidak dapat didua dimensikan. Penggunaan augmented reality sebagai media yang membantu pembelajaran merupakan suatu hal yang akan mendukung dua hal penting untuk peserta didik, yaitu meningkatkan keterampilan berpikir kreatif untuk menghadapi revolusi industri ke-4 dan Penguasaan konsep lebih baik agar Penguasaan konsep yang menjadi sesuatu yang lebih bermakna sehingga dapat dijadikan pertimbangan dalam memecahkan masalah dalam kehidupan sehari-hari.

Salah satu tujuan pendidikan pada abad 21 ini adalah membuat peserta didik berpikir kreatif, baik untuk memecahkan masalah maupun untuk bisa berkomunikasi atau menyampaikan pemikiran mereka. Padahal, penerapan pembelajaran tidak mendorong siswa untuk berpikir kreatif. Dua faktor yang menyebabkan pemikiran kreatif tidak berkembang selama pendidikan adalah kurikulum yang pada umumnya dirancang dengan target materi yang luas, sehingga pendidik lebih fokus menyelesaikan materi daripada pada metode pengajaran yang dapat meningkatkan kemampuan berpikir kreatif (Hasanah dan Surya, 2017).

Lingkungan sosial saat ini membutuhkan kemampuan berpikir kreatif dan keterampilan metakognitif serta kemampuan untuk mengintegrasikan dan mengevaluasi skenario dunia nyata dan keterampilan belajar otentik. Teknologi di abad 21 berfungsi sebagai alat yang luar biasa untuk membentuk dan meningkatkan lingkungan belajar. Dengan menggunakan teknologi digital dengan keterampilan berpikir kreatif adalah cara yang paling efektif untuk mengajar di abad 21 (Brown, 2017).

Keterampilan berpikir kreatif dilakukan dengan memperbaharui kualitas pembelajaran, membantu peserta didik mengembangkan partisipasi dalam pembelajaran, menekankan pembelajaran berbasis masalah, mendorong kerjasama dan komunikasi, meningkatkan keterlibatan dan motivasi peserta didik, meningkatkan kreativitas dan inovasi dalam belajar, mendesain aktivitas belajar yang relevan dengan dunia nyata, dan mengembangkan pembelajaran student-centered. Jika selama ini peserta didik hanya belajar memahami siklus hidup tumbuhan lewat video dan buku pembelajaran, dengan augmented reality proses siklus hidup tumbuhan akan lebih bermakna karena banyak konsep yang bersifat abstrak yang sulit di pahami menjadi lebih nyata dan bermakna (Nelson \& Ahn, 2018).

Melalui pembelajaran menggunakan aplikasi berbasis augmented reality diharapkan dapat meningkatkan Penguasaan konsep dan keterampilan berpikir kreatif peserta didik. Materi yang berkaitan dengan pembelajaran berbasis angmented reality yaitu materi siklus hidup tumbuhan. Materi tentang tumbuhan terutama siklus hidup tumbuhan adalah materi yang sulit. Data yang menunjang pernyataan tersebut dikemukakan oleh Rustiningsih (2017) bahwasannya faktor penyebab kesulitan belajar peserta didik pada materi dunia tumbuhan berasal dari faktor internal dan faktor eksternal. Faktor internal adalah kebiasaan belajar, sedangkan penyebab kesulitan belajar tertinggi dari faktor eksternal disebabkan karena tumbuhan lumut yang sulit diperoleh di lingkungan sekitar dan kegiatan pembelajaran yang dilakukan peserta didik dalam mempelajari materi tumbuhan masih terbatas dalam mendengarkan penjelasan guru dan sumber belajar yang digunakan berasal dari internal.

Selain itu, Zarisma (2013) dalam penelitiannya menyatakan bahwa kesulitan belajar yang dialami peserta didik pada materi dunia tumbuhan ada pada indikator mengidentifikasi ciri umum tumbuhan, menjelaskan struktur tubuh, cara perkembangbiakan tumbuhan paku, tumbuhan berbiji, tumbuhan lumut, klasifikasi dari divisidivisi dalam dunia tumbuhan, membedakan tumbuhan lumut, paku dan tumbuhan berbiji berdasarkan ciri-cirinya, serta menjelaskan peranan anggota dunia tumbuhan bagi kehidupan. Itu artinya submateri mengenai siklus hidup tumbuhan tergolong sulit dan tidak mudah karena objek tumbuhan yang abstrak tidak dapat dilihat secara kasat mata, bahkan banyak tumbuhan yang sulit untuk didapatkan.

Oleh karena itu, peneliti bermaksud untuk melakukan penelitian mengenai penggunaan aplikasi augmented reality untuk meningkatkan Penguasaan tentang siklus hidup tumbuhan dan keterampilan berpikir kreatif.

\section{METODE}

Metode yang digunakan pada penelitian ini adalah quasi experimental design. Desain ini dilakukan dengan pengambilan sampel sebagai kelas kontrol dan kelas eksperimen yang dilakukan tidak secara acak, serta 
dilakukan pengambilan data menggunakan soal tes penguasaan konsep sebelum dan sesudah perlakuan. Kelas kontrol akan melakukan pembelajaran biologi seperti biasa, sementara kelas eksperimen akan melakukan pembelajaran berbasis menggunakan aplikasi berbasis augmented reality menggunakan aplikasi HP Reveal. Desain penelitian yang digunakan adalah tipe non equivalen control group design, yaitu pengambilan sampel dilakukan tidak secara acak dan pengukuran dilakukan sebelum dan setelah diberikannya perlakuan. Desain penelitian ini terdiri dari dua kelas, kelas eksperimen yang diberi perlakuan pembelajaran dengan menggunakan aplikasi augmented reality dan kelas kedua merupakan kelas kontrol yang dilakukan pembelajaran seperti biasanya dengan menggunakan Power Point.

Penelitian ini dilakukan di salah satu SMA Negeri yang berada di Kabupaten Bandung Barat. Populasi pada penelitian ini yaitu peserta didik kelas $X$ IPA yang mempunyai gawai yang memadai. Penentuan subjek penelitian sampel dilakukan secara purposive sampling. Teknik ini digunakan karena kelas yang akan digunakan adalah kelas yang peserta didiknya memiliki gawai yang memadai. Dari sepuluh kelas, sampel yang diambil adalah kelas kelas X IPA 2 dan kelas X IPA 4 yang dimana kelas X IPA 2 digunakan sebagai kelas eskperimen dan kelas X IPA 4 digunakan sebagai kelas kontrol.

Prosedur penelitian diawali dengan tahap persiapan dengan melakukan studi literatur, melakukan studi kurikulum, menyusun dan membuat instrumen penelitian kemudaian melakukan judgement instrumen penelitian pada dosen. Setelah itu dilakukan uji coba instrumen serta analisis instrumen yang akan digunakan dilakukan uji coba instrumen penguasaan konsep terlebih dahulu untuk menentukan kelayakan instrumen penelitian yang telah disusun, lalu data hasil uji coba instrumen penguasaan konsep divalidasi menggunakan ANATES. Prosedur dilanjutkan dengan tahap pelaksanaan yaitu pelaksanaan pengambilan data. Tahap terakhir adalah melaksanakan pengolahan data, membuat pembahasan serta penarikan kesimpulan penelitian dan penulisan skripsi.

Instrumen Penelitian ini terdiri dari soal uraian penguasaan konsep dan soal uraian keterampilan berpikir kreatif. Soal uraian penguasaan konsep dalam penelitian ini berupa pre-test untuk mengetahui pengetahuan konsep awal peserta didik kelas kontrol dan kelas eksperimen, serta posttest ntuk mengetahui penguasaan konsep peserta didik setelah melakukan kegiatan pembelajaran. Sementara tes uraian keterampilan berpikir kreatif untuk mengetahui keterampilan berpikir kreatif peserta didik kelas kontrol dan kelas eksperimen setelah dilakukan kegiatan pembelajaran.

\section{HASIL DAN PEMBAHASAN}

\section{Penguasaan Konsep}

Hasil penelitian diperoleh dari hasil analisis tes penguasaan konsep dan tes keterampilan berpikir kreatif pada kelas eksperimen dan kelas kontrol. Setelah dianalisis, data akhir pada penelitian dijabarkan pada pembahasan hasil penelitian. Hasil penelitian ini diolah dengan menggunakan software Statistical Package for the Social Science
(SPSS) versi 16.0 serta Microsoft Excel versi 2016. Hasil analisis data statistik dapat dilihat pada Tabel 1.

Tabel 1. Analisis statistik perbedaan penguasaan konsep peserta didik

\begin{tabular}{|c|c|c|c|c|c|}
\hline \multicolumn{2}{|c|}{ Jenis Data } & \multicolumn{3}{|c|}{ Pretest } & Postest \\
\hline \multirow{2}{*}{\multicolumn{2}{|c|}{ Grup }} & Eks. & Kontrol & Eks. & Kontrol \\
\hline & & 30 & 30 & 30 & 30 \\
\hline \multicolumn{2}{|c|}{ Rata-rata } & 39,17 & 39,17 & 66,32 & 56,67 \\
\hline \multicolumn{2}{|c|}{ Standar Deviasi } & 10,2 & 9,3 & 15,4 & 17,7 \\
\hline \multicolumn{2}{|c|}{ Min } & 25 & 25 & 42 & 25 \\
\hline \multicolumn{2}{|l|}{$\operatorname{Max}$} & 58 & 50 & 100 & 79 \\
\hline Test of & Sig. & 0,26 & 0,35 & 0,89 & 0,11 \\
\hline $\begin{array}{l}\text { Normality } \\
\text { (Kolmogorov- } \\
\text { Smirnov) }\end{array}$ & $\begin{array}{l}\text { Inter- } \\
\text { pretasi }\end{array}$ & \multicolumn{2}{|c|}{ Normal } & \multicolumn{2}{|c|}{ Normal } \\
\hline Test of & Sig. & \multicolumn{2}{|c|}{0,88} & \multicolumn{2}{|c|}{0,46} \\
\hline $\begin{array}{c}\text { Homogenity } \\
\text { (Levene's Test) }\end{array}$ & $\begin{array}{l}\text { Inter- } \\
\text { pretasi }\end{array}$ & \multicolumn{2}{|c|}{ Homogen } & \multicolumn{2}{|c|}{ Homogen } \\
\hline $\begin{array}{l}\text { Independent } \\
\text { samples t-test }\end{array}$ & $\begin{array}{l}\text { Sig. } \\
\text { Inter- } \\
\text { pretasi }\end{array}$ & Tidak & $\begin{array}{l}51 \\
\text { ignifikan }\end{array}$ & \multicolumn{2}{|c|}{$\begin{array}{c}0,023 \\
\text { Signifikan }\end{array}$} \\
\hline
\end{tabular}

Keterangan: eks. = eksperimen; sig. = signifikansi

Berdasarkan temuan penelitian, pada nilai pretest siswa kelas kontrol dan kelas eksperimen tidak berbeda signifikan, maka dapat dikatakan bahwa peserta didik memiliki tingkat penguasaan konsep yang sama sebelum dilakukan pembelajaran pada materi siklus hidup seksual gymnospermae dan angiospermae. Nilai post-test hasil belajar peserta didik berbeda signifikan, maka dapat dikatakan bahwa setelah pembelajaran, tingkat kemampuan siswa berbeda. Pada data postest, rata-rata nilai yang dicapai oleh kelas eksperimen lebih tinggi dibandingkan dengan rata-rata nilai yang dicapai oleh kelas kontrol.

Peserta didik yang melakukan pembelajaran menggunakan augmented reality memperoleh hasil yang lebih unggul dengan nilai 66 dibandingkan dengan peserta didik yang melakukan pembelajaran menggunakan nonaugmented reality (power point) dengan nilai 57. Hal tersebut sesuai dengan yang dinyatakan oleh Sukamto (2017) bahwa aplikasi augmented reality dapat membantu menyampaikan materi pelajaran kepada peserta didik. Dimana saat pengujian dilakukan, kelompok yang belajar menggunakan aplikasi augmented reality terlihat lebih tertarik dan fokus dalam memahami materi sedangkan untuk kelompok yang belajar menggunakan non-aplikasi augmented reality terlihat lebih cepat bosan dan tidak fokus. Sejalan juga dengan pendapat yang diungkapkan (Rusman, 2013) bahwa media pembelajaran berfungsi untuk membangkitkan perhatian dan motivasi belajar peserta didik dalam belajar, karena media pembelajaran dapat mengakomodasi semua kecakapan peserta didik dalam belajar dan dapat membantu memberikan Penguasaan pada peserta didik. Didukung juga oleh penelitian Hanafi dan Samsudin (2012) yakni dengan menggunakan aplikasi android akan memberikan motivasi tersendiri karena bersifat interaktif dan sederhana.

Kelebihan aplikasi augmented reality adalah dapat memenuhi kebutuhan peningkatan Penguasaan peserta didik, menurut Jaya (2016) pengembangan teknologi augmented reality untuk pelaksanaan kegiatan pembelajaran dapat memenuhi kebutuhan peningkatan keterampilan 
peserta didik, kognitif, dan afektif peserta didik serta menjauhkan peserta didik dalam memahami suatu hal yang abstrak dan kompleks. Sehingga hasil dari tes Penguasaan peserta didik yang menggunakan teknologi augmented reality lebih tinggi dibandingkan dengan yang tidak menggunakan teknologi augmented reality.

Teknologi augmented reality juga dapat memotivasi peserta didik untuk belajar, menurut Zaini (2013) aplikasi yang menggunakan teknologi augmented reality ini dapat menambah motivasi untuk mempelajari materi, sehingga banyak peserta didik yang lebih semangat belajar menggunakan teknologi augmented reality dibandingkan dengan yang tidak menggunakan teknologi augmented reality.

Perbandingan rata-rata nilai pre-test kelas kontrol dan kelas eksperimen dapat dilihat pada Gambar 1.

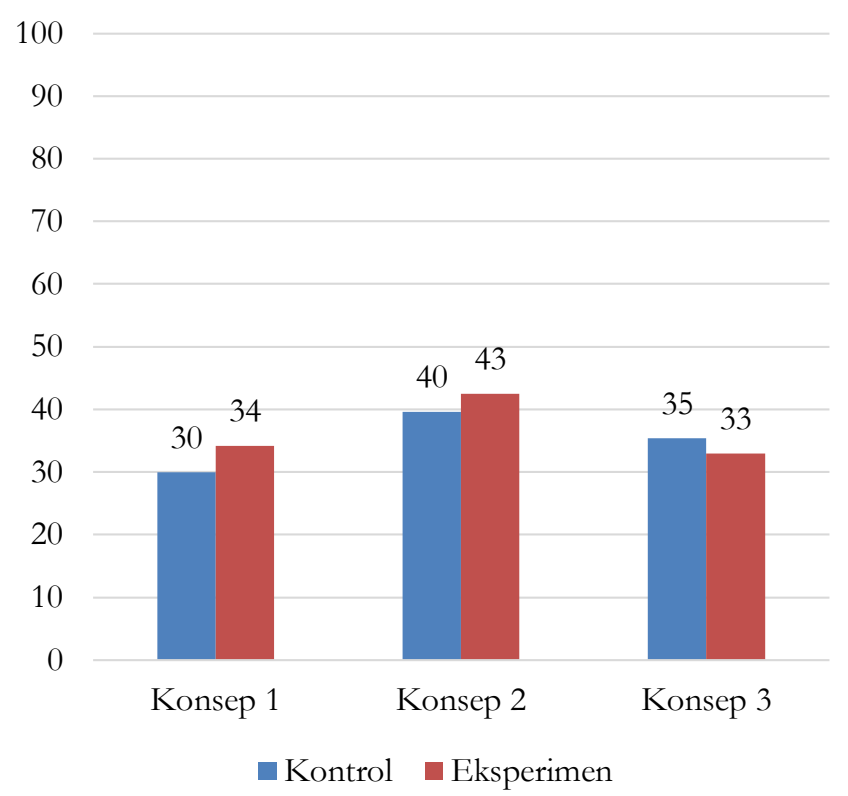

Gambar 1. Perbandingan nilai rata-rata pre-test kelas kontrol dengan kelas eksperimen per konsep

Keterangan:

Konsep 1: konsep mengenai siklus hidup gymnospermae Konsep 2: konsep mengenai siklus hidup angiospermae Konsep 3: konsep mengenai perbedaan antara siklus hidup gymnospermae

Konsep 1 adalah konsep mengenai siklus hidup gymnospermae, konsep 2 adalah konsep mengenai siklus hidup angiospermae, dan konsep 3 adalah konsep mengenai perbedaan antara siklus hidup gymnospermae. Meskipun tidak berbeda signifikan tetapi pada konsep siklus hidup gymnospermae dan siklus hidup angiospermae memiliki rata-rata nilai pada kelas eksperimen lebih tinggi dibandingkan dengan kelas kontrol. Pretest merupakan tes kemampuan awal peserta didik yang mana belum diberikan pembelajaran sebelumnya, peserta didik hanya diberi kesempatan untuk membaca konsep tersebut sebelumya. Terkait dengan hasil prestest tersebut lebih dipengaruhi oleh kemampuan berpikir setiap individu tidak karena pembelajaran berbasis aplikasi augmented reality karena pembelajaran tersebut dilaksanakan setelah pretest selesai. Perbandingan nilai postest pada kelas eksperimen dan kelas kontrol dapat dilihat pada Gambar 2.

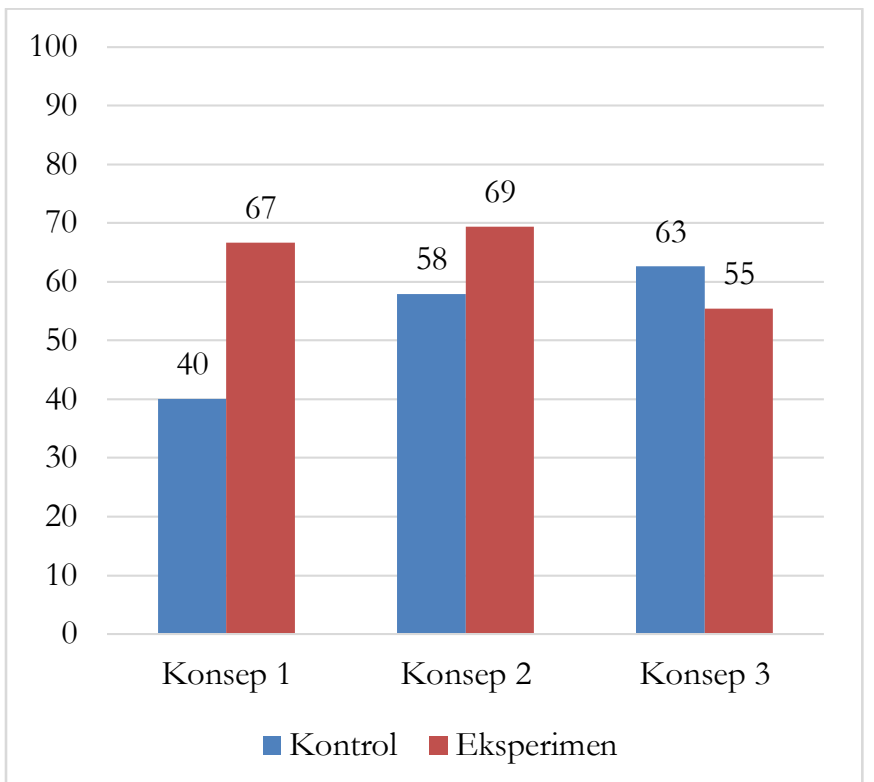

Gambar 2. Perbandingan nilai rata-rata post-test kelas kontrol dengan kelas eksperimen per konsep

Peserta didik yang menggunakan aplikasi augmented reality memiliki nilai penguasaan yang cenderung lebih tinggi dapat dilihat pada Gambar 2 menunjukkan bahwa pembelajaran menggunakan augmented reality dapat membantu penguasaan siswa dalam konsep 1 dan konsep 2. Karakteristik konsep 1 dan konsep 2 adalah mengenai identifikasi tumbuhan gymnospermae dan angiospermae, pada kelas kontrol ini peserta didik cenderung mengandalkan hafalan dari pembelajaran yang diberikan guru sehingga jika peserta didik lupa terhadap konsep, peserta didik tersebut tidak bisa menjawab. Aplikasi augmented reality dapat membantu Penguasaan siswa karena dapat membuat peseta didik menghafal lebih rinci tiap tahapannya. Pada konsep 3 adalah mengenai perbandingan dan perbedaan tumbuhan gymnospermae dan angiospermae yang mana konsep tersebut masih bisa ditalar oleh kemampuan hafalan peserta didik. Aplikasi augmented reality tidak terlalu berpengaruh terhadap karakteristik konsep ini.

Jika dikaitkan dengan hal ini bahwa model mental membantu seseorang atau dalam hal ini peserta didik untuk meningkatkan penguasaan konsep dan Penguasaan tentang suatu hal (World Bank Group, 2015). Hasil ini menunjukan bahwa sifat dari aplikasi AR yaitu dapat memvisualisasikan hal-hal yang dianggap abstrak dan tidak dapat dilihat secara langsung (Novitasari \& Arianto, 2017) tidak menimbulkan pembentukan model 36 mental peserta didik lebih baik dibandingkan dengan penggunaan media berupa tayangan PPT. Hal ini dapat terjadi walaupun augmented reality merupakan salah satu media pembelajaran yang efektif dalam membelajarkan materi pelajaran tidak hanya dalam materi biologi tetapi juga dalam materi pelajaran lain (Gani, 2018). Peningkatan penguasaan konsep yang berbanding lurus dengan mental model peserta didik di kelas eksperimen dikatakan lebih rendah dari kelas eksperimen karena penggunaan augmented reality juga dapat tidak efektif apabila terdapat kekurangan pada hal lain selama pembelajaran, seperti kurangnya upaya peserta didik dalam 
memanfaatkan media pembelajaran berbasis augmented reality sehingga tidak dapat didapatkan sumber hasil visualisasi dengan baik dan secara utuh (Yuliono et al., 2017).

Banyak faktor yang mempengaruhi hasil belajar penguasaan konsep tersebut, pada kelas kontrol pembelajaran dilakukan dengan menggunakan media power point untuk menampilkan gambar siklus hidup dan menggunakan papan tulis untuk menuliskan beberapa konsep yang perlu di tulis, dengan cara belajar seperti itu banyak peserta didik yang mudah bosan sehingga tidak memperhatikan saat pembelajaran. Pada kelas eksperimen pembelajaran dilakukan dengan menggunakan aplikasi augmented reality sehingga semua peserta didik ikut berperan aktif dalam pembelajaan, yang tadinya peserta didik hanya duduk dan memperhatikan kedepan menjadi peserta didik duduk dengan aplikasi augmented reality nya masing-masing dan memperhatikan video pembelajaran yang sudah di modifikasi oleh peneliti dengan cara menggunakan aplikasi augmented reality lebih meningkatkan minat dan motivasi peserta didik dalam proses pembelajaran dibandingkan peserta didik yang tidak menggunakan aplikasi augmented reality.

Penggunaan teknologi berbasis augmented reality dapat mempengaruhi kemampuan penguasaan konsep peserta didik dalam memahami makna pembelajaran dan penerapannya dalam kehidupan sehari-hari. Seseorang dapat dikatakan menguasai suatu konsep jika orang tersebut benar-benar memahami konsep yang dipelajarinya sehingga mampu menjelaskan dengan menggunakan katakata sendiri sesuai dengan pengetahuan yang dimilikinya tetapi tidak mengubah makna yang ada didalamnya. Konsep diri merupakan salah satu hal terpenting yang dapat mempengaruhi kehidupan seseorang. Ada beberapa pengertian tentang konsep diri, konsep diri adalah gagasan tentang diri sendiri yang mencakup keyakinan, pandangan, dan penilaian seseorang terhadap dirinya sendiri. Konsep diri terdiri atas bagaimana seseorang merasa tentang dirinya sendiri menjadi manusia, dan bagaimana seseorang menginginkan dirinya sendiri menjadi manusia sebagaimana diharapkan (Burn, 1997).

\section{Keterampilan Berpikir Kreatif}

Keterampilan berpikir kreatif mempunyai empat indikator diantaranya meliputi kemampuan berpikir lancer (fluency), berpikir luwes (flexibility), berpikir asli (originality), dan berpikir merinci (elaboration). Pada kelas kontrol dan eksperimen keempat indicator tersebut muncul dengan nilai yang variasi (Munandar, 2009). Hasil analisis data statistik dapat dilihat pada Tabel 2.

Hasil Penelitian ini diperoleh dari jawaban peserta didik melalui soal uraian keterampilan berpikir kreatif, dimana hasil tersebut menunjukan tidak ada perbedaan antara kelas yang menggunakan pembelajaran dengan menggunakan aplikasi augmented reality dengan kelas yang tidak menggunakan aplikasi augmented reality. Pembelajaran berbasis augmented reality yang dilakukan dianggap kurang berkualitas seperti waktu pembelajaran yang kurang banyak, seperti yang dinyatakan oleh Yennitas et al., (2012) bahwa kegiatan pembelajaran berbasis augmented reality memiliki beberapa kekurangan diantaranya memerlukan waktu yang lama sehingga sulitnya pengaturan jadwal untuk dapat melakukannya. Hal tersebut sejalan dengan yang dikemukakan oleh $\mathrm{Hu}$ (dalam Widodo dkk, 2016) bahwa pengembangan keterampilan berpikir kreatif memerlukan waktu yang lama. Dan didukung oleh Rogers (dalam Munandar, 2009), faktor-faktor yang dapat mendorong terwujudnya kreativitas individu diantaranya dorongan dari dalam diri sendiri (motivasi intrinsik) dan dorongan dari lingkungan (motivasi ekstrinsik).

Tabel 2. Analisis statistik keterampilan berpikir kreatif peserta didik

\begin{tabular}{|c|c|c|c|}
\hline \multicolumn{2}{|c|}{ Grup } & Eksperimen & Kontrol \\
\hline \multicolumn{2}{|c|}{$\mathrm{N}$} & 30 & 30 \\
\hline \multicolumn{2}{|c|}{ Rata-rata } & 22,61 & 20,22 \\
\hline \multicolumn{2}{|c|}{ Standar Deviasi } & 3,93 & 6,96 \\
\hline \multicolumn{2}{|c|}{ Min } & 10 & 5 \\
\hline \multicolumn{2}{|c|}{ Max } & 28,3 & 28,3 \\
\hline Test of Normality & Sig. & 1,06 & 0,67 \\
\hline $\begin{array}{l}\text { (Kolmogorov- } \\
\text { Smirnov) }\end{array}$ & Interpretasi & \multicolumn{2}{|c|}{ Normal } \\
\hline Test of Homogenity & Sig. & \multicolumn{2}{|c|}{0,46} \\
\hline (Levene's Test) & Interpretasi & \multicolumn{2}{|c|}{ Homogen } \\
\hline Independent & Sig. & \multicolumn{2}{|c|}{0,1} \\
\hline samples t-test & Interpretasi & \multicolumn{2}{|c|}{ Tidak Signifikan } \\
\hline
\end{tabular}

Keterangan: eks. = eksperimen; sig. = signifikansi

Arisanti et al. (2016) menyatakan bahwa ada beberapa hal yang menyebabkan rendahnya hasil tes keterampilan berpikir kreatif diantarnya; (1) tidak ada latihan secara kontinu yang dilakukan siswa untuk menguasai keempat aktivitas keterampilan berpikir kreatif. (2) keterbatasan waktu sehingga tidak ada pematauan terhadap aktivitas keterampilan berpikir kreatif siswa, karena siswa apabila sudah menyelesaikan tugas proyek sudah dianggap menguasai aktivitas-aktivitas keterampilan berpikir kreatif. (3) peran guru yang kurang maksimal melibatkan siswa untuk mengembangkan keterampilan berpikirnya, seharusnya guru mampu melibatkan siswa dalam pemikiran yang lebih tinggi seperti yang diungkapkan Vygotski (dalam Kuswana, 2011) yang menyatakan bahwa pendidik harus mencoba untuk membantu peserta didik terlibat dalam pemikiran tingkat yang lebih tinggi melalui bantuan terstruktur. Selain itu seperti yang diungkapkan Ayan (2002) banyak orang tidak mengembangkan daya kreatif mereka karena tidak diberi tahu cara memanfaatkan keterampilan kreatif alami ataupuan cara mengembangkan berbagai teknik. Perbandingan nilai hasil tes keterampilan berpikir kreatif dapat dilihat pada Gambar 3.

Pada indikator fluency kelas eksperimen memperoleh hasil yang lebih tidak jauh berbeda dibandingkan kelas kontrol. Berdasarkan Gambar 4.13. nilai keterampilan berpikir lancar eksperimen lebih tinggi dibandingkan dengan kelas kontrol walaupun hasilnya tidak jauh bebeda. Kelas eksperimen mencapai nilai yang lebih unggul dibandingkan dengan kelas kontrol pada indikator ini. Menurut Ejiwale (2012) salah satu karakteristik dari pembelajaran berbasis teknologi yaitu pembelajaran yang mengijinkan siswa untuk memiliki lebih dari satu jawaban benar, sehingga lingkungan seperti itu dapat memberikan kesempatan kepada siswa untuk menemukan solusi yang kreatif. 


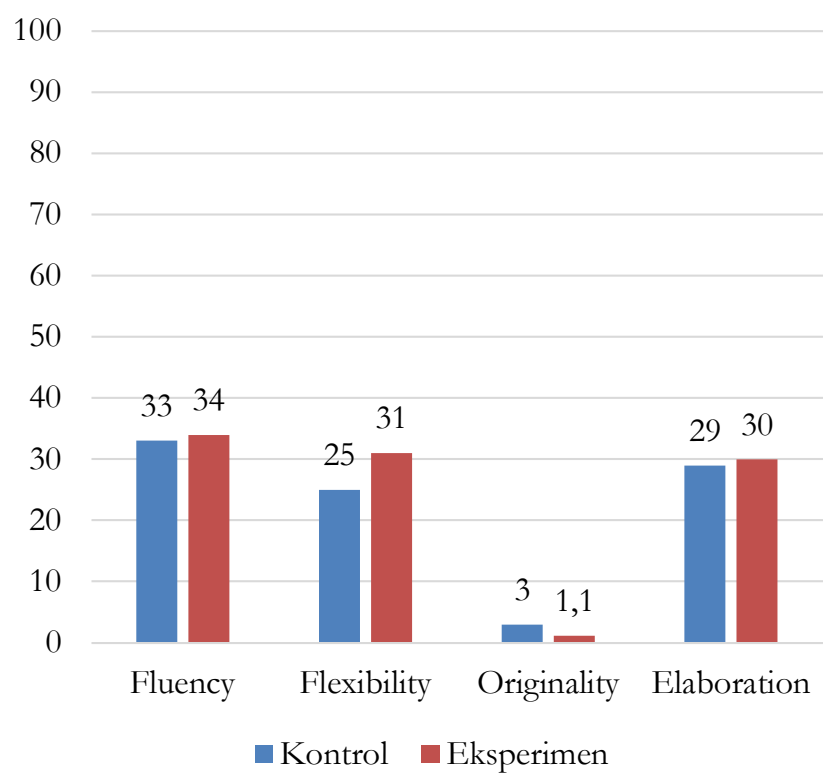

Gambar 3. Rata-rata nilai test keterampilan berpikir kreatif kelas kontrol dan eksperimen tiap indikator

Tingginya persentase pada indikator fluency menunjukkan bahwa pada umumnya siswa telah memiliki kemampuan dalam menghasilkan banyak ide atau gagasan yang dihasilkan dari pemikirannya sendiri secara cepat. Gagasan yang dihasilkan dari proses berpikir ini lebih ditekankan pada kuantitas atau banyaknya gagasan yang dihasilkan, daripada kualitasnya (Munandar, 1999).

Dalam kaitannya dengan dunia pendidikan khususnya dalam proses pembelajaran di kelas, Wang (2011) menyebutkan bahwa terdapat empat aspek yang mempengaruhi kemampuan berpikir kreatif siswa, yaitu faktor kognitif, motivasi, kepribadian, dan faktor sosial. Secara kognitif Williams (dalam De Caroli, 2013).

Pada kelas kontrol jawaban yang diberikan peserta didik sudah cukup banyak dan bervariasi bagi sebagian peserta didik, pada indikator ke dua yaitu flexibility kelas eksperimen memperoleh hasil yang lebih tinggi dibandingkan kelas kontrol Dengan demikian, kelas eksperimen mencapai nilai yang lebih tinggi dibandingan dengan kelas kontrol pada indikator ini. Hal tersebut terjadi karena kegiatan pembelajaran non-augmented reality yang dilakukan pada penelitian ini kurang mendukung keterampilan siswa dalam berpikir luwes, seperti tidak adanya pertanyaan dalam lembar kerja siswa yang menuntut siswa untuk mampu berpikir luwes. Disamping itu menurut Hennessey dan Amabile (dalam Maisya, 2014) menyatakan bahwa keterampilan seseorang dipengaruhi oleh faktor intrinsik yang merujuk pada motivasi siswa, motivasi juga dapat dipengaruhi oleh berbagai hal seperti kondisi lingkungan dan suasana kelas. Disamping itu sebenarnya setiap orang memiliki kemampuan dalam berpikir kreatif, tetapi potensi kreatif tersebut berbedabeda. Tidak ada orang yang sama sekali tidak memiliki kreativitas yang diperlukan hanyalah cara untuk mengembangkannya (Kim, 2006).

Terbatasnya sudut pandang seseorang mengenai suatu hal dapat menghambat berbagai kemungkinan yang dapat terjadi. Sementara dalam ranah sains, kegiatan penelusuran yang fleksibel akan mendukung penemuan-penemuan pada hal-hal baru, berdasarkan perbedaan interpretasi suatu data temuan (Shively, 2011).

Sementara menurut Tylor (dalam Munandar, 2009), berpikir kreatif merupakan kemampuan untuk melihat, memikirkan hal-hal yang tidak lazim, membutuhkan informasi yang sepertinya tidak berhubungan, dan membuat solusi-solusi baru atau ide-ide baru. Pada dasarnya kreativitas dan kemampuan berpikir kreatif memiliki kesamaan, yaitu dapat menghasilkan sesuatu yang baru dengan cara membuat keterikatan dari beberapa ide yang sepertinya tidak berhubungan.

Pada indikator ketiga originality kelas eksperimen memperoleh hasil yang lebih rendah dibandingkan kelas kontrol Perbedaan yang ditunjukkan tidak terlalu berbeda. Ketika menghadapi suatu masalah para pemikir kreatif akan mengombinasikan konsep dan hal-hal berbeda (Michalko, 2012). Keterampilan dalam menghasilkan banyak ide atau gagasan dinilai merupakan langkah awal dalam upaya mencari solusi terhadap suatu masalah dengan cara pemikiran yang relatif (Shively, 2011).

Siswa yang telah memiliki kemampuan ini akan mampu menyikapi suatu masalah dan menemukan caracara yang baru dan inovatif dalam menyelesaikan dan mencari jalan keluarnya. Hal ini didukung dengan asumsi Weisberg (1986) yang menyatakan bahwa seseorang yang kreatif haruslah memiliki pemikiran yang berbeda yang efektif, serta mampu terus berimprovisasi mencari hal-hal yang baru (novelty) dan unik (Munandar, 1999).

Pada indikator ke empat yaitu elaboration kelas eksperimen maupun kelas kontrol memperoleh hasil yang tidak berbeda. Kemampuan elaborasi tidak hanya terbatas pada sejauh mana siswa dapat memberikan paparan yang jelas atau alasan logis yang disampaikan secara mendetail, tetapi juga pada kemampuan dalam mengembangkan suatu gagasan (Munandar, 1999), sehingga menghasilkan suatu gagasan yang lebih dapat dipahami (Shively, 2011).

Berdasarkan uraian diatas, diketahui bahwa indikator fluency, flexibility, dan elaboration pada kelas eksperimen lebih tinggi dibandingkan kelas kontrol, kecuali pada indikator originality. Sehingga tidak dapat disimpulkan bahwa seseorang yang memiliki nilai fluency yang tinggi pasti memiliki keterampilan berpikir kreatif yang tinggi pula. Demikian juga apabila nilai fluency yang tinggi bukan berarti memiliki nilai flexibility atau originality atau elaboration yang tinggi pula. Hal tersebut karena pada penelitian ini indikator keterampilan berpikir kreatif yang diukur memiliki koefisien korelasi yang rendah terhadap indikator lainnya (Kim dalam Prakoso, 2016).

Berdasarkan uraian diatas, diketahui bahwa indikator fluency, flexibility, dan elaboration pada kelas eksperimen lebih tinggi dibandingkan kelas kontrol, kecuali pada indikator originality. Sehingga tidak dapat disimpulkan bahwa seseorang yang memiliki nilai fluency yang tinggi pasti memiliki keterampilan berpikir kreatif yang tinggi pula. Demikian juga apabila nilai fluency yang tinggi bukan berarti memiliki nilai flexibility atau originality atau elaboration yang tinggi pula.

Pada penelitian ini aplikasi angmented reality belum memberikan dampak yang signifikan pada kemampuan 
berpikir kreatif peserta didik di kelas eksperimen karena hasil yang diperoleh pada kelas eksperimen sama dengan hasil yang diperoleh oleh kelas kontrol.

\section{SIMPULAN}

Pembelajaran menggunakan aplikasi augmented reality memfasilitasi penguasaan konsep peserta didik tentang siklus hidup tumbuhan. Terjadi perbedaan yang signifikan antara kelas kontrol dengan kelas eksperimen pada hasil tes penguasaan sehingga Aplikasi augmented reality dapat memfasilitasi penguasaan konsep peserta didik. Namun tidak terjadi perbedaan yang signifikan pada keterampilan berpikir kreatif.

Penelitian ini juga mengungkapkan bahwa keterampilan berpiki kreatif siswa yang melakukan pembelajaran berbasis aplikasi augmented reality lebih baik dibandingkan siswa yang melakukan pembelajaran berbasis non-aplikasi augmented reality. Hal tersebut memberikan implikasi kepada guru untuk selalu sadar terhadap keterampilan berpikir kreatif yang dimiliki siswa. Karena banyak dari guru Biologi yang hanya fokus terhadap Penguasaan konsep siswa saja karena berbagai hal. Sehingga pembelajaran berbasis aplikasi augmented reality dapat dijadikan pendekatan yang efektif untuk diterapkan oleh guru dalam pembelajaran Biologi dan mencetak sumber daya manusia selanjutnya yang memiliki kemampuan bersaing di era revolusi industri ke-4 yang akan mereka hadapi

Aplikasi augmented reality cocok digunakan pada materi dengan jenjang kognitif tinggi. Hal ini dapat membantu guru menjelaskan suatu konsep yang jenjang kognitifnya tinggi kepada siswa dengan lebih mudah. Walaupun augmented reality ini tidak berpengaruh terhadap jenis kelamin, itu artinya guru harus memerhatikan setiap siswanya, tidak ada hal yang khusus terkait jenis kelamin karena pada dasarnya setiap siswa itu istimewa.

\section{REFERENSI}

Arisanti. (2015). Employing augmented-reality-embedded instruction to disperse the imparities of individual differences in earth science learning. Journal of Science Education and Technology, 24(6), 835-847.

Ayan. (2002). The Effect of an Augmented reality Enhanced Mathematics Lesson on Student Achievement and Motivation. Journal of STEM Educ a Tion, 16(3), 4048.

Brown, J. S. (2017). Smart Social Networking : 21 Century Teaching. Research in Pedagogy, 7(1), 21-29.

Gani. (2018). Analisis keterampilan berpikir kreatif siswa pada konsep dasar biologi. (SKRIPSI). UPI. Bandung

Guoping, L. I., Yun, H. O. U., \& Aizhi, W. U. (2017). Fourth Industrial Revolution : Technological Drivers, Impacts and Coping Methods. Chin. Geogra. Sci., 27(4), 626-637.

Hanafi. (2013). Peningkatan Kemampuan Berpikir Kreatif Matematik Siswa Melalui Pendekatan Kontruktivisme di Kelas VII Sekolah Menengah Pertama (SMP) Negeri 2 Banyuasin III. Jurnal Pendidikan Matematika,
$7(2), 1-12$.

Hasanah, S. O. (2017). Computer programming skill and gender difference: An empirical study. American Journal Of Scientific And Industrial Research, 7(1), 1-9.

Hsu, Y., Lin, Y., \& Yang, B. (2017). Impact of augmented reality lessons on students' STEM interest. Research and Practice in Technology Enhanced Learning, 12(2), 1-14.

Ilomäki, L., Paavola, S., Lakkala, M., \& Kantosalo, A. (2014). Digital competence - an emergent boundary concept for policy and educational research. Education Information and Technology, 23(5) 100-123.

Kuswana. (2011). Implementasi Model Pembelajaran Eksperimental berbantu media interaktif untuk meningkatkan keterampilan aplikasi siswa SMK. (online). Diakses dari : http://Repository.UPI.edu

Munandar, U. (2009). Pengembangan Kreativitas Anak Berbakat. Jakarta: Rineka Cipta.

Mustaqim, I. (2016). Pemanfaatan Augmented reality Sebagai Media Pembelajaran. Jurnal Pemikir Pendidikan, 13(2), 174-183.

Nelson, M., \& Ahn, B. (2018). Work in Progress: Developing Engineering Students' Professional Develop-ment Skills through Augmented and Virtual Reality Gaming Environments Work-In-Progress: Developing engineering students' professional development skills through augmented and virtual. ASEE Annual Conference, 24(8) 123-134.

Novitasari, D., \& Arianto, F. (2017). Pengembangan Augmented reality Berbasis Android Materi Sistem Pernapasan Manusia Untuk Siswa Kelas Xi Ipa Di Sma Negeri 1 Porong. Jurnal Mahasiswa Teknologi Pendidikan, 1(1), 1-5

Rusman, S. S. (2013). Individual Behavior, Culture, and Social Change. The Behavior Analyst, 2(2), 133-151

Rustininingsih, A. (2017). Analisis Kesulitan Belajar Materi Tumbuhan Di Mojokerto. Prosiding TEP \& PDs, 4(5), 204-210.

Sukanto, M. A. (2017). Augmented reality Anatomi Sistem Pernapasan Menggunakan Leap Motion Controller Sebagai Media Pembelajaran Medis. Universitas Sumatera Utara. Jurnal Tabularasa PPS UNIMED, 12(3), 224-234.

Torralba, J. F. J. (2015). ARBOOK: Development and Assessment of a Tool Based on Augmented reality for Anatomy. Science Education and Technology, 24(12), 119124.

Widodo, A. (2018). Analisis Kemampuan Berpikir Kreatif dan Proses Pengembangan Kemampuan Berpikir Kreatif Siswa SMP pada Pembelajaran Biologi. Indonesia Journal of Biology Education, 1(1), 21-28.

World Bank Group. (2015). Thinking with mental models. World Development Report 2015.

Yennitas. (2016). Exploring 21st Century Skills and Learning Environments for Middle School Youth Exploring 21st Century Skills and Learning Environments for Middle. International Journal of School Social Work, 1(1), 1-25.

Yuliono, T., Sarwanto, \& Peduk, R. (2017). Keefektifan Media Pemelajaran Augmented reality Terhadap Penguasaan Konsep Sistem Pencernaan Manusia. Jurnal Pendidikan Dasar. Indonesia Journal of Pedagogic 
Education, 1(1), 21-28.

\section{Conflict of Interest Statement}

The author(s) declare that the research was conducted in the absence of any commercial or financial relationships that could be construed as a potential conflict of interest.

\section{How to Cite}

Mardiyah, F. H., Widodo, A., \& Rochintaniawati, D. (2020). Penggunaan aplikasi augmented reality untuk memfasilitasi penguasaan konsep peserta didik tentang siklus hidup tumbuhan dan keterampilan berpikir kreatif. Assimilation: Indonesian Journal of Biology Education, 3(2), 55-62.

Zarisma, U. (2013). Identifikas Kesulitan Belajar Peserta didik Pada Materi Dunia Tumbuhan Kelas X SMA

Negeri 1 Sambas. Jurnal Pendidikan, 22(10), 123-144. 